\title{
Summer Squash Production Using Conservation Tillage
}

\author{
D.S. NeSmith', G. Hoogenboom ${ }^{2}$, and D.V. McCracken ${ }^{3}$ \\ The University of Georgia, Georgia Station, Griffin, GA 30223-1797
}

Additional index words. cultural practices, vegetable crops, cover crops, soil properties, no-till, Cucurbita pepo

\begin{abstract}
Three summer squash (Cucurbita pepo L.) cultivars were grown using conventional tillage and no-till soil management practices during 1991 and 1992 in the mountain regions of Georgia. Soil bulk density and $\mathrm{N}$ content as well as crop dry weight, leaf area, and yield were monitored to assess the potential for using conservation tillage in squash production. Soil bulk density of the surface $(0$ to $10 \mathrm{~cm})$ layer under no-till exceeded. that under conventional tillage at planting by $0.25 \mathrm{Mg} \cdot \mathrm{m}^{-3}$, and 1 month after planting by as much as $0.16 \mathrm{Mg} \cdot \mathrm{m}^{-3}$. However, growth-limiting bulk densities $\left(>1.45 \mathrm{Mg} \cdot \mathrm{m}^{-3}\right)$ did not occur. Total soil $\mathbf{N}$ to a $30-\mathrm{cm}$ depth was similar for the two tillage regimes. There were no significant cultivar $\times$ tillage interaction effects on plant dry weight, leaf area, or crop yield. Total yields were similar for the two tillage regimes; however, early yield during 1991 was $27 \%$ less using no-till. There is potential for the use of conservation tillage in summer squash production in the southeastern United States. However, the current lack of registered herbicides for weed control and possible early market price incentives are likely disadvantages to widespread acceptance of such cultural practices.
\end{abstract}

Vegetable crops are vital to the rural economy of the mountain regions and other areas throughout the southeastern United States having sloping topography. Widespread use of tillage-intensive land preparation practices threatens agricultural productivity, environmental quality, and ultimately, the economy and sustainability of these rural communities. The Soil Conservation Service estimates that soil erosion potential in these regions ranges from 18 to $45 \mathrm{t} \cdot \mathrm{ha}^{-1}$ annually. Conservation tillage practices and cover crops are often the most cost effective means of controlling soil erosion (Blevins et al., 1983; Langdale et al., 1979). Sustainable land management strategies have not been sufficiently evaluated for vegetable crop production in the southeastern United States, and as a result, they have not been widely adopted by vegetable growers.

Tillage can have a marked impact on soil properties such as soil water content, soil compaction, and soil temperature (Blevins et al., 1983; NeSmith et al., 1987a, 1987b; Smittle and Threadgill, 1982). However, crop species, and even cultivars, may respond differently to the soil conditions that develop under various tillage and cover-crop systems. Cover crops

Received for publication 15 Mar. 1993. Accepted for publication 29 June 1993. A contribution of the Univ. of Georgia Agr. Expt. Sta., Georgia Station, Griffin. This research was supported by state and Hatch Act funds allocated to the Georgia Agr. Expt Stas. We gratefully acknowledge the assistance of the staff at the Georgia Mountain Branch Experiment Station in the completion of this research.The cost of publishing this paper was defrayed in part by the payment of page charges. Under postal regulations, this paper therefore must be hereby marked advertisement solely to indicate this fact.

'Dept. of Horticulture.

${ }^{2}$ Dept. of Biological and Agricultural Engineering. ${ }^{3}$ Dept. of Crop and Soil Science. may interfere both physically and chemically with the establishment of subsequent crops (Barnes and Putnam, 1986; Weston, 1990).

Research concerning summer squash production using various tillage practices is limited, and generally only a single cultivar has been evaluated. Knavel and Herron (1986) demonstrated that squash yields from no-till plots were similar to those grown with conventional tillage; however, plant dry weight and stand establishment were usually poorer under no-till. Squash are considered to be sensitive to soil compaction and root restriction (NeSmith, 1993; Smittle and Williamson, 1977). Squash yields were reduced when disk tillage was used instead of conventional tillage with a moldboard plow, and the yield loss was attributed to soil compaction (Smittle and Threadgill, 1982; Smittle et al., 1984). The objective of our research was to evaluate the effects of conventional and conservation tillage on growth and yield of three summer squash cultivars.

This research was conducted during 1991 and 1992 on a Transylvania clay loam (fine-loamy, mixed, mesic Cumulic Haplumbrept) at the Georgia Mountain Experiment Station in Blairsville. Summersquash cultivars were planted in the spring each year following a winter cover crop of rye (Secale cereale L.). The rye cover crop was established in the fall using disk tillage, and was killed with $N$-(phosphonomethyl) glycine (glyphosate) at $2.24 \mathrm{~kg}$ a.i./ha 3 to 4 weeks before establishment of the summer squash plots.

Squash plots were laid out in a completely randomized design with a split-plot arrangement replicated three times. The main plots were tillage (conventional tillage and no-till), and the subplot was squash cultivar ('Dixie', 'Lemondrop', and 'Senator'). The conventional tillage system consisted of moldboard plowing to $\approx 30-\mathrm{cm}$ depth followed by disking to a $15-\mathrm{cm}$ depth before planting. A no-till planter was used to mark rows for hand seeding in both treatments. For the no-till treatment, the soil surface remained covered with rye residue, except for a narrow band of soil that was disturbed by the planter. Soil coverage by rye in the no-till treatments was $60 \%$ to $70 \%\left(\approx 1500 \mathrm{~kg} \cdot \mathrm{ha}^{-1}\right)$ in 1991 and $80 \%$ to $100 \%$ $\left(\approx 2500 \mathrm{~kg} \cdot \mathrm{ha}^{-1}\right)$ in 1992 . Main plots were 12 rows wide $\times 11 \mathrm{~m}$ long. Row width was $90 \mathrm{~cm}$, and plant spacing was $60 \mathrm{~cm}$ in the row. The three squash cultivars were randomly assigned to four-row subplots.

On 23 May 1991 and 20 May 1992, three to four seeds per hill of the three cultivars were planted by hand 3 to $5 \mathrm{~cm}$ deep in the two tillage treatments. Plants were thinned to one plant per hill after emergence.Drip-irrigation tubing was placed on the surface in the row to supplement rainfall as needed. Typically, 25 to $30 \mathrm{~mm}$ of irrigation was applied weekly in the absence of precipitation. Fertilizer was surface-applied at planting each year at (in $\left.\mathrm{kg} \cdot \mathrm{ha}^{-}{ }^{1}\right) 50 \mathrm{~N}-, 30 \mathrm{P}$, and $84 \mathrm{~K}$. An additional 84 $\mathrm{kg} \mathrm{N} / \mathrm{ha}$ was surface-applied as a sidedress application 3 weeks after emergence. Weeds were controlled in the plots by a combination of recommended herbicides, tillage in the conventional tillage plots, and hand weeding. Insects were controlled as needed using recommended insecticides.

Soil data were collected from the tillage main plots only. Soil bulk density was determined to a $25-\mathrm{cm}$ depth using a soil coring method similar to that described by NeSmith et al. (1986). Samples for bulk density were taken in the row at planting during 1992, and 1 month after planting during 1991 and 1992. Micro-Kjeldahl procedures (Nelson and Sommers, 1972) were used to determine total soil $\mathrm{N}$ for soil cores taken to a $30-\mathrm{cm}$ depth. Data for $\mathrm{N}$ were obtained at planting and 1 month after planting during 1992 only.

Plant dry weight, leaf area, and yield data were collected from the cultivar subplots. Dry weight and leaf area were determined weekly from week 2 to week 7 of the experiment for each year. Two plants per plot were harvested at each sample interval, and leaf area was determined using NeSmith's (1992) procedure. Whole-plant dry weight was subsequently determined after oven-drying at $60 \mathrm{C}$ for 3 to 5 days. Yields were taken from the entire length $(11 \mathrm{~m})$ of an undisturbed harvest row. Harvests of fruit having a transverse diameter of at least $4 \mathrm{~cm}$ were made two to three times weekly for a total of eight harvests during 1991 beginning on 1 July and a total of five harvests during 1992 beginning on 6 July. The first three harvests were considered "early" yield.

For variables associated with main plots only (soil measurements), analysis of variance procedures appropriate for a completely randomized block experimental design were used to determine effects of tillage. For variables pertaining to cultivar subplots and tillage (crop measurements), analysis of variance procedures for a split-plot experimental design were used. Least significant difference tests were 
used to separate differences among means at $P$ $<0.05$.

In the no-till plots, soil bulk density was significantly higher in the upper $10 \mathrm{~cm}$ of soil at planting and 1 month after planting (Table 1). Fall disking and natural soil consolidation during the winter likely caused this soil condition, and the lack of spring tillage to disrupt this compacted layer allowed the high bulk density to persist (NeSmith et al., 1987a). Below the $15-\mathrm{cm}$ soil depth, bulk density was similar for both tillage treatments. High bulk density can have adverse effects on root growth of crops, but the degree of influence depends on factors such as soil moisture and soil texture. Daddow and Warrington (1983) presented a model for growth-limiting bulk densities as related to soil texture. According to this model, the growth-limiting bulk density for the soil texture in our experiment was 1.45 $\mathrm{Mg} \cdot \mathrm{m}^{-3}$. Bulk densities approached, but never exceeded, this value.

Tillage did not significantly influence soil $\mathrm{N}$ status. The upper $30 \mathrm{~cm}$ of soil contained an average $7.4 . \%$ and $11.9 \% \mathrm{~N}$ at planting and 1 month after planting, respectively, during 1992 Other research has demonstrated that certain nutrients typically become stratified under no-till systems (Blevins et al., 1977; Hargrove et al., 1982). Such stratification occurs gradually and usually requires minimal soil disturbance for several years for maximum expression. The current study did not involve continuous no-till since disk tillage was used to establish the winter cover crop. Considering this pattern of soil management and the short duration of tillage treatments, it is not surprising that no significant differences in total soil $\mathrm{N}$ were found.

No significant cultivar $\times$ tillage interactions occurred with the plant variables measured over 2 years. Leaf area and plant dry weight were different among cultivars during both years, but most frequently during 1992 (data not presented). Generally, 'Senator' had the most vigorous vegetative growth. Early and total yields were similar among cultivars during both years.

Plant dry weight and leaf area were less for the no-till treatment the first 3 to 4 weeks after sowing during 1991 (Table 2). By 5 weeks after sowing, and thereafter, there were no significant tillage effects for these plant growth variables. There were no differences in plant dry weight and leaf area due to tillage during 1992 (data not presented). The slower growth with no-till early in the 1991 growing season was likely related to lower soil temperatures for this treatment. Although soil temperatures were not available for this experiment, a previous report (NeSmith et al., 1987a) indicated that, in the southeastern United States, soil temperatures at $2.5 \mathrm{~cm}$ can be as much as 5 to SC cooler when using no-till following a winter cover crop, as compared to conventional tillage. Also, Knavel et al. (1977) indicated that cool soils associated with no-till systems adversely affect stand establishment and early growth, particularly for vegetable crops planted early in the season.

Early yield during 1991 was less for no-till

Table 1. Soil bulk density at 0 - to $10-\mathrm{cm}$ and $15-$ to $25-\mathrm{cm}$ depths under conventional and no-till systems used to produce summer squash during 1991 and 1992 at Blairsville, Ga.

\begin{tabular}{|c|c|c|c|c|c|}
\hline \multirow[b]{3}{*}{ Tillage } & \multicolumn{5}{|c|}{ Soil bulk density $\left(\mathrm{Mg} \cdot \mathrm{m}^{-3}\right)$} \\
\hline & \multicolumn{2}{|c|}{$0-10 \mathrm{~cm}$} & & \multicolumn{2}{|c|}{$15-25 \mathrm{~cm}$} \\
\hline & 1991 & 1992 & & 1991 & 1992 \\
\hline \multicolumn{6}{|c|}{ At planting } \\
\hline Conventional & --- & $1.09 \mathrm{~b}^{2}$ & . & --- & $1.32 \mathrm{a}$ \\
\hline No-till & --- & $1.34 \mathrm{a}$ & & --- & $1.35 \mathrm{a}$ \\
\hline \multicolumn{6}{|c|}{1 month after planting } \\
\hline Conventional & $1.22 \mathrm{~b}$ & $1.25 \mathrm{~b}$ & & $1.42 \mathrm{a}$ & $1.35 \mathrm{a}$ \\
\hline No-till & $1.38 \mathrm{a}$ & $1.33 \mathrm{a}$ & & $1.44 \mathrm{a}$ & $1.36 \mathrm{a}$ \\
\hline
\end{tabular}

${ }^{\mathrm{z}}$ Mean separation in columns within the two sampling times at $P \leq 0.05$ by $\mathrm{F}$ test.

Table 2. Average whole-plant dry weight and leaf area of three summer squash cultivars grown using conventional tillage and no-till 3 and 4 weeks after planting during 1991 at Blairsville, Ga.

\begin{tabular}{|c|c|c|c|c|}
\hline \multirow[b]{2}{*}{ Tillage } & \multicolumn{2}{|c|}{ Dry wt (g/plant) } & \multicolumn{2}{|c|}{ Leaf area $\left(\mathrm{cm}^{2} /\right.$ plant $)$} \\
\hline & Week 3 & Week 4 & Week 3 & Week 4 \\
\hline Conventional & $1.7 \mathrm{a}^{\mathrm{z}}$ & $8.6 \mathrm{a}$ & $296 \mathrm{a}$ & $1144 \mathrm{a}$ \\
\hline No-till & $1.3 \mathbf{a}$ & $4.1 \mathrm{~b}$ & $174 b$ & $551 \mathrm{~b}$ \\
\hline
\end{tabular}

${ }^{z}$ Mean separation in columns within the two sampling times at $P \leq 0.05$ by $\mathrm{F}$ test.

Table 3. Average early and total yields (in megagrams per hectare) of three summer squash cultivars grown using conventional tillage and no-till during 1991 and 1992 at Blairsville, Ga.

\begin{tabular}{llllr}
\hline & \multicolumn{2}{c}{ Early yield $^{z}$} & \multicolumn{2}{c}{ Total yield $^{y}$} \\
\cline { 2 - 4 } Tillage & 1991 & 1992 & 1991 & 1992 \\
\hline Conventional & $5.6 \mathrm{a}^{\mathrm{x}}$ & $5.4 \mathrm{a}$ & $21.2 \mathrm{a}$ & $9.0 \mathrm{a}$ \\
No-till & $4.1 \mathrm{~b}$ & $4.3 \mathrm{a}$ & $19.6 \mathrm{a}$ & $7.0 \mathrm{a}$
\end{tabular}

${ }^{\mathrm{z}}$ Early yield consisted of the first three harvests, both years.

yTotal yield for 1991 was from eight harvests beginning 1 July; 1992 was from five harvests beginning 6 July. ${ }^{x}$ Mean separation in columns within the two sampling times at $P \leq 0.05$ by $\mathrm{F}$ test.

than for conventional tillage (Table 3). This again was likely due to cool early season soils, as already discussed. Flower counts (data not presented) indicated there was a 3- to 5-day delay in flowering and, thus, fruit-set for all cultivars under no-till during 1991. Total yields were similar for the two tillage treatments during both years. Total yield overall during 1992 was lower than in 1991 , probably due to lower temperatures early in the 1992 growing season (data not presented). Also, there were only five harvests during 1992 as compared to eight during 1991.

These data suggest that it is possible to produce several summer squash cultivars successfully in the southeastern United States using conservation tillage. However, early yields may be reduced when using no-till; hence, if a premium price for an early crop exists, no-till would be disadvantageous. Notill did not reduce total yields in the current study. Soil compaction needs to be monitored carefully to avoid growth-limiting bulk densities common with conservation tillage. Also, effective weed control is essential for obtaining high yields. In the current experiment, the no-till plots were hand-weeded. Since this is not feasible for most growers, the success of no-till squash production will depend ultimately on the availability of herbicides; currently, few herbicides are labeled for use in summer squash.

\section{Literature Cited}

Barnes, J.P. and A.R. Putnam. 1986. Evidence for allelopathy by residues and aqueous extracts of rye (Secale cereale). Weed Sci. 34:384390.

Blevins,R.L.,M.S. Smith, G.W.Thomas, and W.W. Frye.1983.Influence of conservation tillage on soil properties.J.Soil\&WaterConserv. 38:301304

Blevins, R. L., G.W. Thomas, and P.L. Cornelius. 1977. Influence of no-tillage and nitrogen fertilization on certain soil properties after 5 years of continuous corn. Agron. J. 69:383-386.

Daddow, R.L. and G.E. Warrington. 1983. Growth-limiting soil bulk densities as influenced by soil texture. Watershed Systems Development Group Rpt.WSDG-TN-00005. U.S. Dept. Agr. Forestry Serv., Fort Collins, Colo.

Hargrove, W. L., J.T. Reid, J.T. Touchton, and R.N. Gallaher. 1982. Influence of tillage practices on the fertility status of an acid soil double-cropped to wheat and soybeans. Agron. J. 74:684-687.

Knavel, D. E., J. Ellis, and J. Morrison. 1977. The effects of tillage systems on the performance and elemental absorption byselected vegetable crops. J. Amer. Soc. Hort. Sci. 102:323-327.

Knavel, D.E. and J.W. Herron. 1986. Response of vegetable crops to nitrogen rates in tillage systems with and without vetch and ryegrass. J. Amer. Soc. Hort. Sci. 111 :502-507.

Langdale, G. W., A.P. Bamett, R.A. Leonard, and W.G. Fleming. 1979. Reduction of soil erosion by the no-till system in the southern Piedmont. Trans. Amer. Soc. Agr. Eng. 22:82-92.

Nelson, D.W. and L.E. Sommers. 1972. A simple digestion procedureforestimation of total nitrogen in soils and sediment. J. Environ. Qual. $1: 423425$.

NeSmith, D.S. 1992. Estimating summer squash leaf area nondestructively.HortScience 27:77.

NeSmith,D.S.1993. nfluence of root restriction on two cultivars of summer squash (Cucurbita pepo L.). J. Plant Nutr. 16:421431.

NeSmith, D. S., W.L. Hargrove, D.E. Radcliffe, 
E.W. Tollner, and H.H. Arioglu. 1987a. Tillage and residue management effects on properties of an Ultisol and double-cropped soybean production. Agron. J. 79:57-576.

NeSmith, D. S., W.L. Hargrove, E.W. Tollner, and D.E. Radcliffe. 1986. A comparison of three soil surface moisture and bulkdensity sampling techniques. Trans. Amer. Soc. Agr. Eng. 29: $1297-$ 1299.

NeSmith, D. S., D.E. Radcliffe, W.L. Hargrove,
R.L. Clark, and E.W. Tollner. 1987b. Soil compaction in double-cropped wheat and soybeans on an Ultisol. Soil Sci. Soc. Amer. J. 51:183-186.

Smittle, D.A. and E.D. Threadgill. 1982. Response of squash to irrigation, nitrogen fertilization, and tillage systems. J. Amer. Soc. Hort. Sci. 107:437440.

Smittle, D.A., E.D. Threadgill, and W.L. Dickens. 1984. Effects of nitrogen fertilization method and tillage system on squash growth, nutrient uptake, and fruit yield. Comun. Soil Sci. Plant Anal. 15:541-552.

Smittle, D.A. and R.E. Williamson. 1977. Effect of soil compaction and nitrogen source on growth and yield of squash. J. Amer. Soc. Hort. Sci. 102:535-537.

Weston, L.A. 1990. Cover crop and herbicide influence on row crop seedling establishment in no-tillage culture. Weed Sci. 38:166171. 